\title{
Field Evaluation of Transgenic Papaya Lines Carrying the Coat Protein Gene of Papaya ringspot virus in Taiwan
}

\author{
Huey-Jiunn Bau, Department of Plant Pathology, National Chung Hsing University, Taichung, Taiwan, R. O. C.; \\ Ying-Huey Cheng, Department of Horticulture, Taiwan Agricultural Research Institute, Wufeng, Taiwan, R. O. C.; \\ Tsong-Ann Yu and Jiu-Sherng Yang, Department of Botany, National Chung Hsing University; Pan-Chi Liou, \\ Chi-Hsiung Hsiao, and Chien-Yih Lin, Department of Horticulture, Taiwan Agricultural Research Institute; and \\ Shyi-Dong Yeh, Department of Plant Pathology, National Chung Hsing University
}

\begin{abstract}
Bau, H.-J., Cheng, Y.-H., Yu, T.-A., Yang, J.-S., Liou, P.-C., Hsiao, C.-H., Lin, C.-Y., and Yeh, S.-D. 2004. Field evaluation of transgenic papaya lines carrying the coat protein gene of Papaya ringspot virus in Taiwan. Plant Dis. 88:594-599.

Four transgenic papaya lines expressing the coat protein (CP) gene of Papaya ringspot virus (PRSV) were evaluated under field conditions for their reaction to PRSV infection and fruit production in 1996 to 1999. Plants were exposed to natural virus inoculation by aphids in two adjacent fields in four different plantings at the same sites. None of the transgenic lines showed severe symptoms of PRSV whereas control nontransgenic plants were $100 \%$ severely infected 3 to 5 months after planting. In the first and second trials, 20 to $30 \%$ of the transgenic plants showed mild symptoms consisting of confined mottling or chlorotic spots on leaves. The number of transgenic plants with mild symptoms fluctuated according to the season and weather conditions, with a tendency to increase in the winter or rainy season and decrease in the summer. Also, the incidence of the mild symptoms in the third trial increased significantly due to infection by root rot fungi during the rainy season. Interestingly, there was no apparent adverse effect on fruit yield and quality in transgenic plants with mild symptoms. In the first and second experiments, transgenic lines yielded 10.8 to 11.6 and 54.3 to 56.7 times more marketable fruit, respectively, than controls. All transgenic plants produced fruit of marketable quality with no ringspots or distortion.
\end{abstract}

Papaya (Carica papaya L.) is a tropical and subtropical perennial fruit crop with a commercial production cycle of about 3 years (11). Production is limited primarily by susceptibility to Papaya ringspot virus (PRSV), a member of the genus Potyvirus $(12,13)$, which is transmitted nonpersistently by aphids. PRSV destroys the photosynthetic capacity of the canopy, leading to reductions in fruit quality and yield, loss of vegetative vigor, and eventual mortality. Although tolerant selections of papaya have been described $(4,5)$, resistance to PRSV has not been found within $C$. papaya. Other control measures, such as quarantine and eradication, have provided only temporary or partial solutions to the problem (20).

A nitrous acid-induced mild strain PRSV HA5-1 (18) has been used in Taiwan and Hawaii to control the disease by cross protection and provide economic

Corresponding author: S. D. Yeh

E-mail: sdyeh@nchu.edu.tw

This study was supported in part by the Council of Agriculture of the Republic of China on Taiwan.

Accepted for publication 20 December 2003.

Publication no. D-2004-0315-02R

(C) 2004 The American Phytopathological Society return for papaya production $(17,18,20,21)$. However, the strain-specific protection limits the application of the mild strain in other areas of the world (20). Other drawbacks of this control measure include the adverse effects of mild strains on papaya, the additional cost for inoculating and indexing the seedlings, possible occurrence of severe revertants, and breakdown under severe disease pressure (20).

Pathogen-derived resistance (14) is an effective strategy recently applied to develop transgenic crops resistant to numerous plant viruses. Fitch et al. (7) successfully introduced the coat protein $(\mathrm{CP})$ gene of the mild strain PRSV HA5-1 into papaya via particle bombardment and obtained transgenic papaya plants that were resistant to the homologous PRSV HA strain (8). One transgenic line (55-1) showed virtual immunity to PRSV infection under greenhouse and field conditions $(8,10)$. However, the protection of R1 plants of transgenic line 55-1 was strain specific, only active against the local Hawaiian strains (16). These results indicate that transgenic line 55-1 can provide a promising way to control PRSV in Hawaii, but may not be effective in other regions.

Recently, we have developed an efficient method for transformation of papaya with the CP gene of the severe PRSV strain YK from Taiwan. The transgene was intro- duced into papaya via Agrobacteriummediated transformation following liquidphase wounding of embryogenic tissues with carborundum (2). Of 45 transgenic lines, 2 were immune and 10 were highly resistant to PRSV YK (1). These PRSVresistant lines also showed a high degree of broad-spectrum resistance against PRSV strains from Hawaii, Thailand, and Mexico under greenhouse conditions (1). In this investigation, we report results of the evaluation of four selected highly resistant lines under field conditions.

\section{MATERIALS AND METHODS}

Test plants of transgenic lines. Transgenic papaya lines were obtained by Agrobacterium-mediated transformation (2). Papaya genotypes included in the field trials consisted of $\mathrm{R}_{0}$ plants of PRSV CPtransgenic female 'Tainung No. 2' lines 16-0-1, 17-0-1, 17-0-5, and 18-2-4, and plants of nontransgenic Tainung No. 2 as control. Previous tests under greenhouse conditions showed that $R_{0}$ plants of these four lines were highly resistant to mechanical inoculation with the homologous PRSV YK (1). Plantlets of vegetative clones of these four transgenic lines were multiplied by in vitro shoot-tip micropropagation as described previously (1) and used for the experiments.

Field location and experimental designs. Field trials were conducted under permits issued by the Agriculture Council of the Republic of China on Taiwan. An isolated site was chosen on experimental farms at the Taiwan Agriculture Research Institute located at Wufang, Taichung. The area was surrounded by high shrubs, which were used as green fences to avoid the dispersion of pollen. Field trials were conducted in compliance with the guidelines of the Council of Agriculture. Two sites were selected $10 \mathrm{~m}$ apart. The first trial started in September 1996 with 60 plants of three transgenic lines (16-0-1, 17-0-1, and 17-0-5) in three replicated plots (each with 20 plants) in a completely randomized block design (CRBD), and randomly mixed with the nontransgenic controls of Tainung No. 2 papaya (three blocks with a total of 60 plants). The test plants were 2.5 and $2 \mathrm{~m}$ apart and within rows, respectively. Two guard rows were planted with nontransgenic Tainung No. 2. The second 
trial started in November 1996 with the same experimental design, except that transgenic line 17-0-1 was replaced by line 18-2-4. The third trial, which started in May 1998, was set at the same site as the first trial after an 18-month investigation. The fourth trial started in March 1999 on the same site as the second trial after a 16month investigation. In all, 80 plants in each of three lines (16-0-1, 18-2-4, and nontransgenic Tainung No. 2) were planted individually in the third and the fourth trials in a randomized complete block design (RCBD). All four test fields were exposed to natural infection by aphids; no artificial inocula or diseased plants were provided in the field.

Evaluation of virus resistance and fruit yield. The resistance of transgenic lines to virus infection was evaluated in the four trials by monitoring symptom development every 2 weeks. Furthermore, leaves with and without viral symptoms were tested for PRSV infection by doubleantibody sandwich enzyme-linked immunosorbent assay (DAS-ELISA) (3) using an antiserum against PRSV particles (19). Fruit yields were determined by recording fruit production of all plants in each line during a 9- and 6-month harvest period in the first and second trial, respectively. Fruit weights collected from each plot were subjected to variance analysis using the SAS program (SAS Institute, Cary, NC) to evaluate relationships among variables. Fruit harvested were rated for symptoms and marketable size. Healthy fruit were considered marketable, whereas distorted fruit with ringspots were considered unmarketable.

\section{RESULTS}

Development of symptoms. In the first trial, some nontransgenic control plants were infected 29 days after planting and all gradually developed severe symptoms within 5 months after planting. Typical severe PRSV symptoms on nontransgenic controls consisted of leaf mosaic and distortion, water-soaking streaks on petioles and stems, ringspots and distortion on fruit, and stunting in growth. Infections were confirmed with DAS-ELISA using an antiserum against PRSV. All plants without symptoms were ELISA negative when tested against PRSV antiserum. None of the plants from transgenic lines $16-0-1,17-$ $0-1$, and 17-0-5 showed severe symptoms 18 months after planting (Figs. 1A and B and $2 \mathrm{~A}$ ).

Similarly, no transgenic plants in lines $16-0-1,17-0-5$, and $18-2-4$ in the second trial developed severe symptoms 16 months after planting, even though they were exposed to a severe challenge pressure from the diseased plants in the adjacent site from the first trial (Fig. 2B). All control plants of the second trial were infected with PRSV and exhibited typical severe symptoms 3 months after planting (Fig. 2B).
The third trial was set at the same site as the first. Two months after planting, 16 and $9 \%$ of the plants of transgenic lines 16-0-1 and 18-2-4, respectively, displayed chlorotic spots or mottling on leaves before flowering. In this trial, 38 and 32 plants of transgenic lines 16-0-1 and 18-2-
4 , respectively, were infected with root rot fungi and died gradually during the rainy season. We replanted the lost plants, but they grew slowly and weakly. After 6 months, $87 \%(70 / 80)$ and $78 \%(63 / 80)$ of the plants of transgenic lines $16-0-1$ and $18-2-4$, respectively, were infected by

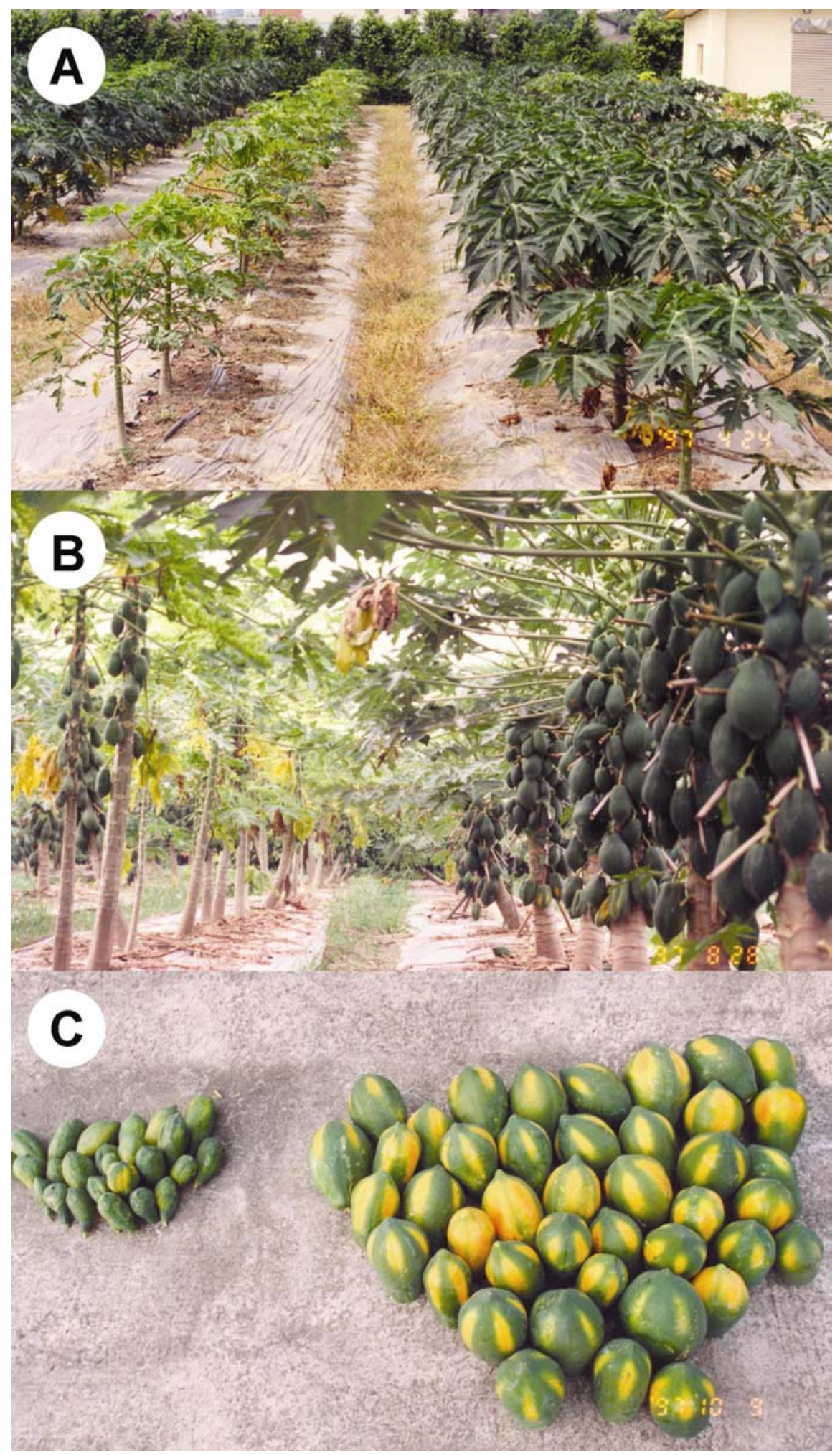

Fig. 1. Views of the second field trial of line 18-2-4 transgenic papaya at A, 6 months and $\mathbf{B}, 11$ months after transplanting. A and $\mathbf{B}$, Papaya ringspot virus-infected plants of the nontransgenic control Tainung No. 2 are shown on the left and transgenic plants of line 18-2-4 on the right. C, Fruit of the corresponding rows harvested at 11 months after transplanting. 
PRSV, displaying severe mottling on the canopy. Most plants were not in optimal growing conditions and were further damaged by a severe tropical storm in the summer of 1998; therefore, we ceased the trial in November 1998 and removed all the plants from the field.

In the fourth trial (started in March 1999), plants were grown at the same site as the second trial after fallowing and flooding for 4 months to suppress the root fungi. The transgenic plants showed a high level of resistance to PRSV infection. Only
$4 \%(3 / 80)$ plants of transgenic line 16-0-1 and $3 \%(2 / 80)$ of transgenic line 18-2-4 exhibited mild mottling on leaves 17 months after planting. Nontransgenic controls all were infected with PRSV and displayed typical severe mosaic symptoms 5 months after planting (data not shown).

Mild symptoms on transgenic lines. Some transgenic plants displayed mild leaf symptoms of mottling or chlorotic spots. ELISA tests showed that these plants were infected by PRSV. Despite PRSV infection, symptoms were restricted to some

\section{A}

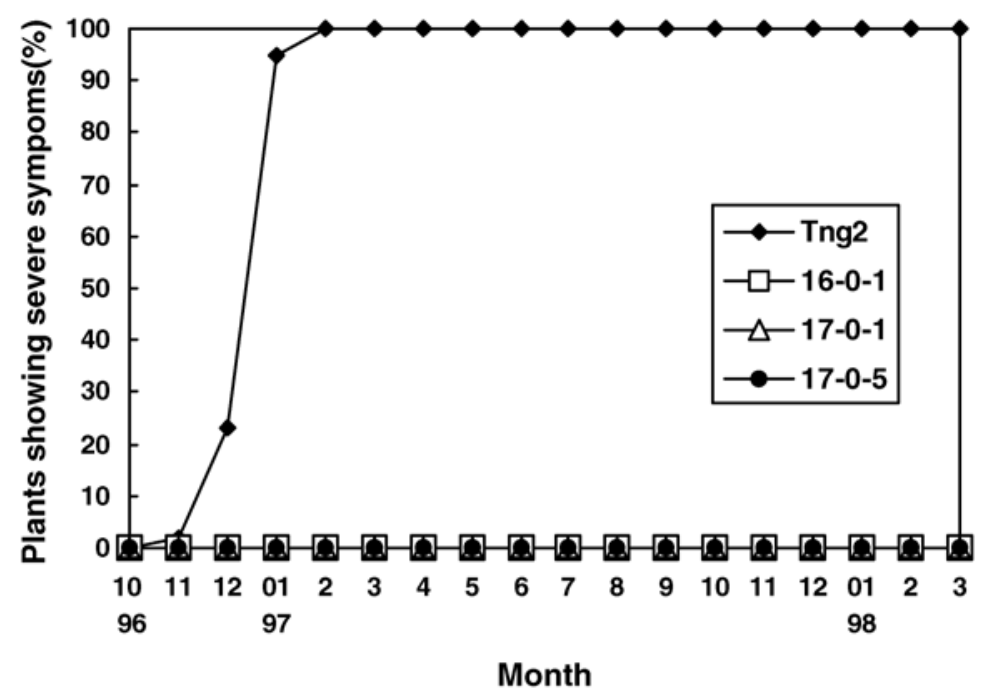

B

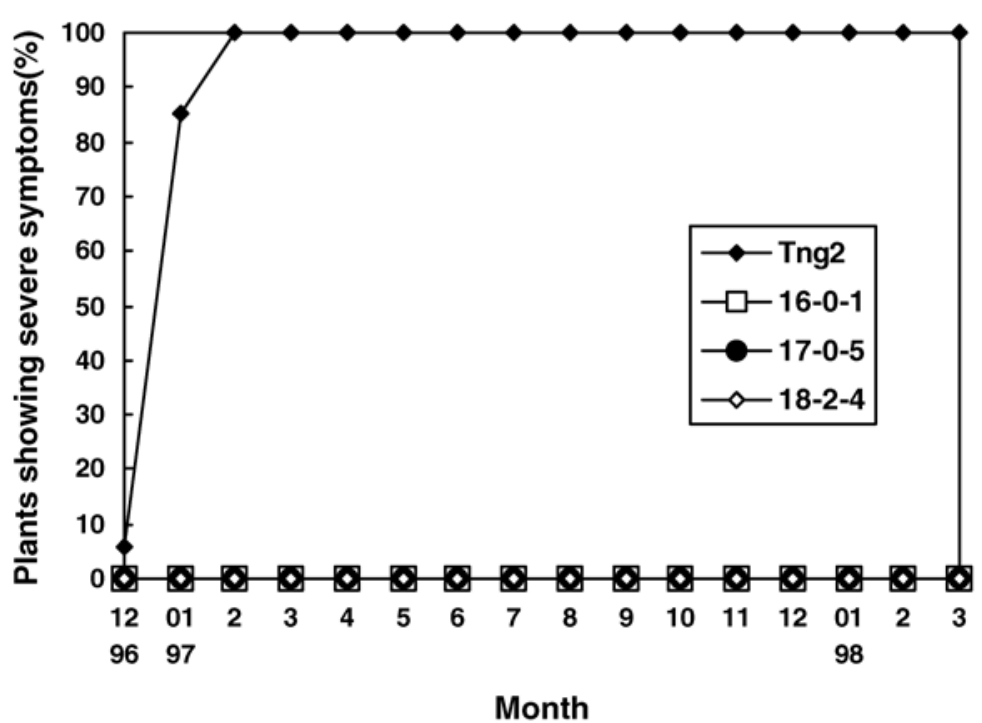

Fig. 2. Disease incidences recorded every month based on plants showing severe symptoms of mosaic and distortion on leaves, water-soaking streaks on stem and petioles, and ringspots and distortion on fruit, and Papaya ringspot virus infection confirmed by double-antibody sandwich enzyme-linked immunosorbent assay. A, First field trial, from October 1996 to March 1998. B, Second field trial, from December 1996 to March 1998.

leaves, and no apparent adverse effects on growth and fruit production were noticed. Over the course of the experiments in the first and second trials, about 20 to $30 \%$ of the plants in each transgenic line exhibited mild leaf symptoms (Fig. 3A and B). The number of transgenic plants with mild symptoms fluctuated according to the season and weather conditions. In the summer (July to September), the number was lower. In all, 51 transgenic plants in the first trial and 22 transgenic plants in the second trial showed changes of leaf symptoms from mild mottling to chlorotic spots, and chlorotic spots disappeared from leaves of 27 plants in two trials. In the winter (November to February) or during the rainy season (April to June), the number of transgenic plants expressing mild mottling increased gradually (Fig. 4A and B).

Fruit yield and quality. Fruit yield was determined by adding total weights of marketable and unmarketable fruit produced by each line. After a 9-month harvest during the first trial starting in May 1997, the total fruit weight of transgenic lines 16-0-1, 17-0-1, and 17-0-5 was $1,500,1,555$, and $1,446 \mathrm{~kg}$, respectively, whereas control plants produced only 561 kg. After a 6-month harvest during the second trial starting in August 1997, the total fruit production for transgenic lines 16-0-1, 17-0-5, and 18-2-4 was 1,127, 1,134 , and $1,086 \mathrm{~kg}$, respectively, while control plants produced only $354 \mathrm{~kg}$. Analysis of variance indicated that the yield increases of 157 to 177 and 206 to $219 \%$ for transgenic lines over nontransgenic controls in the first and the second trials, respectively, was significant. In contrast, yield values among transgenic lines in both trials were not significantly different (Table 1). In the fourth trial, fruit yield collected over a 7-month period for transgenic lines $16-0-1$ and $18-2-4$ was 1,156 and $1,200 \mathrm{~kg}$, respectively. The yield of nontransgenic control Tainung No. 2 was $345 \mathrm{~kg}$.

All transgenic plants produced fruit showing no ringspots or distortion and all were classified marketable (Fig. 1C). Therefore, marketable fruit produced by transgenic lines 16-0-1, 17-0-1, and 17-0-5 in the first trial were $1,500,1,555$, and $1,446 \mathrm{~kg}$. Control plants produced only $134 \mathrm{~kg}$ of marketable fruit. Transgenic lines 16-0-1, 17-0-5, and 18-2-4 in the second trial produced 1,127, 1,134, and $1,086 \mathrm{~kg}$, respectively, of marketable fruit. Most of the fruit from the control plants were severely distorted, small in size, and had numerous ringspots; and only $20 \mathrm{~kg}$ were marketable. The marketable fruit of transgenic lines in the first and second trials were 10.8 - to 11.6 -fold and 54.3- to 56.7 -fold more, respectively, than that of controls. In the fourth trial, all the fruit produced from the transgenic lines were marketable, whereas control plants had no 
marketable fruit due to early PRSV infection before pollination.

\section{DISCUSSION}

Test plants were subjected to constant attack by viruliferous aphids for a period ranging from 16 to 18 months, a normal production cycle for papaya production in Taiwan, during the course of field experiments. The second trial, in particular, was under extremely high inoculum pressure, generated from the diseased plants from the adjacent field of the first trial. Our field studies demonstrated that the CP transgenic papaya lines exhibited a high level of resistance to PRSV infection. When compared with the limited effectiveness reported for other PRSV control strategies, such as cross-protection (20), and the genetic PRSV tolerance identified in papaya germ plasm $(5,22)$, the transgenic lines provided much better protection for papaya production.

About 20 to $30 \%$ of transgenic plants developed mild symptoms on a few leaves caused by PRSV as confirmed by ELISA. These plants grew normally and produced marketable fruit. In some cases, plants with a few chlorotic spots on the upper leaves recovered and became symptomless under summer conditions. Subsequent analysis by ELISA detected no PRSV in these recovered plants. Our results differ from previous observations reported by Lius et al. (10) and Ferreira et al. (6), who indicated that homozygous and heterozygous transgenic papaya are almost immune to PRSV infection, except for two to three heterozygous plants with PRSV symptoms on small side branches in a field test in Hawaii. We speculate that the climatic factors, such as precipitation and temperature, may affect the ability of the transgenic papaya lines to completely resist PRSV infection. During the rainy seasons, numerous transgenic plants displayed mottling symptoms on leaves. PRSV isolates collected from infected plants in the field did not overcome the resistance of transgenic papaya plantlets in the greenhouse, except for 5-19, an isolate that caused wilting and severe mottling on nontransgenic and transgenic young plantlets, respectively (data not shown). Unfavorable conditions for papaya growth, such as low temperatures in the winter, high soil moisture during the rainy season, or infection by root rot fungi, may affect the physiological status of transgenic plants. Thus, the level of resistance to PRSV infection is lower in plants weakened by abiotic or biotic factors. Most recovery occurs during summer time; therefore, we think that higher temperatures enhanced the growth of plants and thus strengthened the degree of resistance.

Plant development may be another cause affecting the transgenic resistance. Tennant et al. (15) showed that older hemizygous transgenic plants offer higher level of re- sistance to homologous PRSV than young plants. Our third trial indicated that $16 \%$ of the plants of transgenic line 16-0-1 and 9\% of the plants of transgenic line 18-2-4 were infected by PRSV before flowering. This phenomenon likely is due to the incomplete establishment of gene silencing in younger plants.

Although transgenic plants displayed mild symptoms, plant growth and production of marketable fruit were not affected. Infected transgenic plants have the ability to restrict the virus to leaves and not allow it to invade fruit that were ELISA negative when tested with PRSV antiserum (data not shown). Fruit yield and fruit quality analyses of each transgenic line showed a tremendous increase compared with the controls. Our results clearly indicate that these transgenic papaya lines have a great potential for providing economic returns to papaya growers in Taiwan.

Tennant et al. (16) have reported that, although the resistance in transgenic papaya line 55-1 is highly effective against homologous PRSV strains from the Hawaiian Islands, it is not protected against heterologous strains from other regions. In-
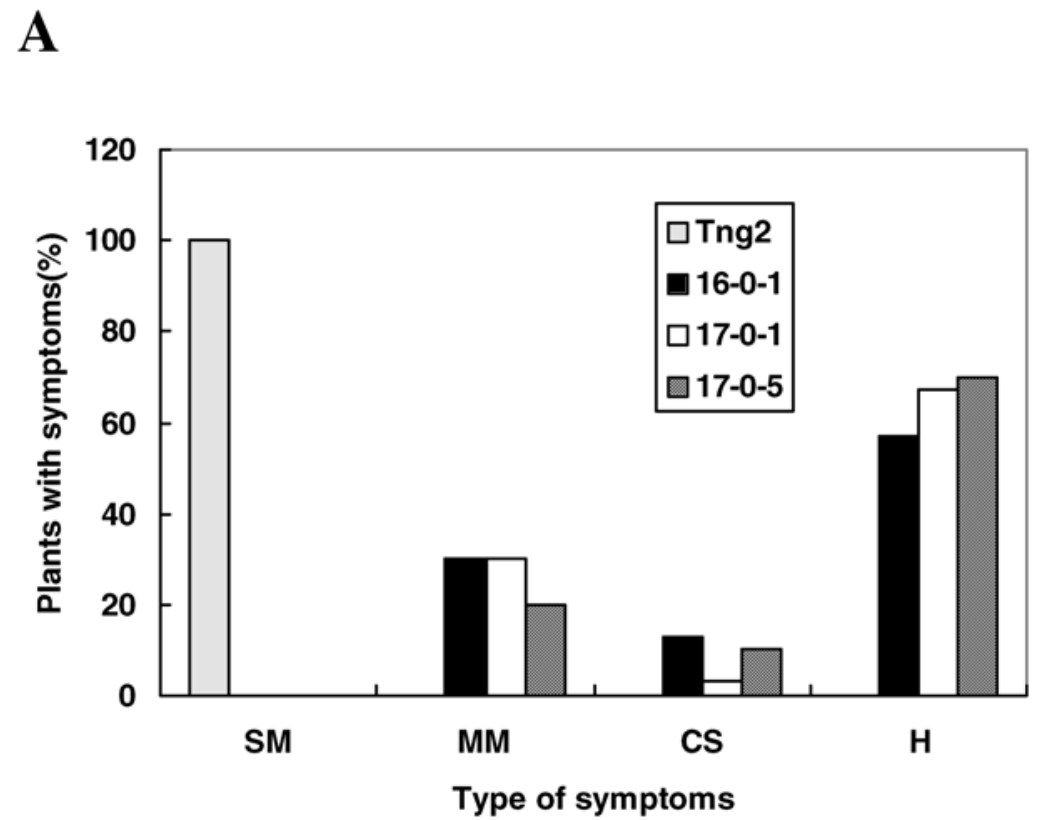

B

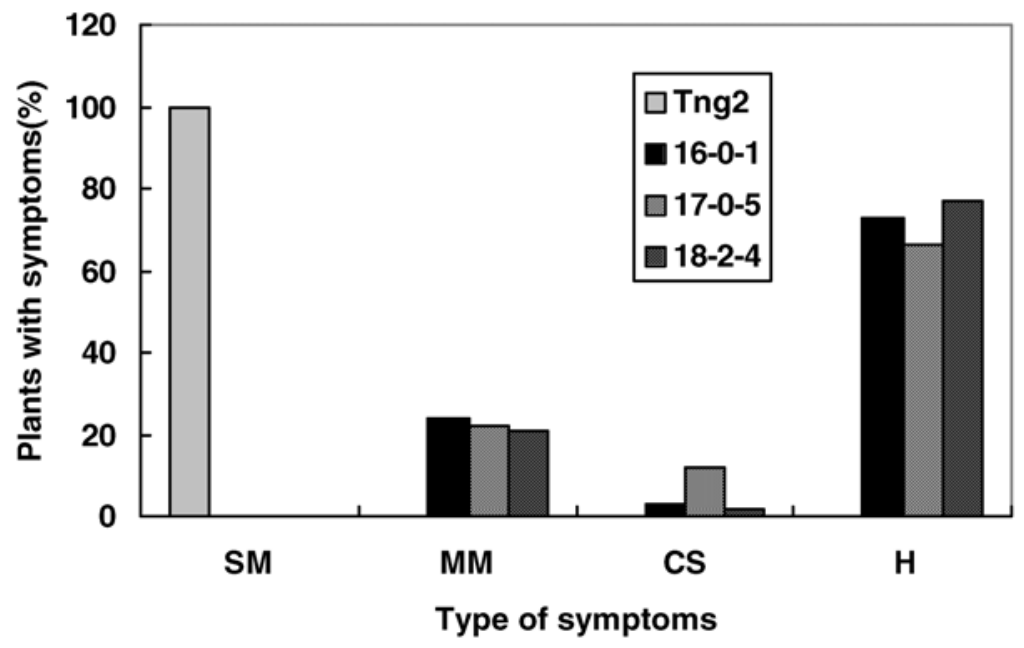

Fig. 3. Percentages of transgenic and nontransgenic control plants showing SM (severe symptoms, including mosaic and distortion on leaves, water-soaking streaks on stem and petioles, and distorted fruit with ringspots), MM (mild mottling on leaves, but fruit were normal without visual symptoms), CS (only few chlorotic spots on upper leaves), and $\mathrm{H}$ (without symptoms and negative in enzymelinked immunosorbent assay using the antiserum to Papaya ringspot virus; 19) during $\mathbf{A}$, the first trial 18 months after planting and $\mathbf{B}$, the second trial 16 months after planting. 


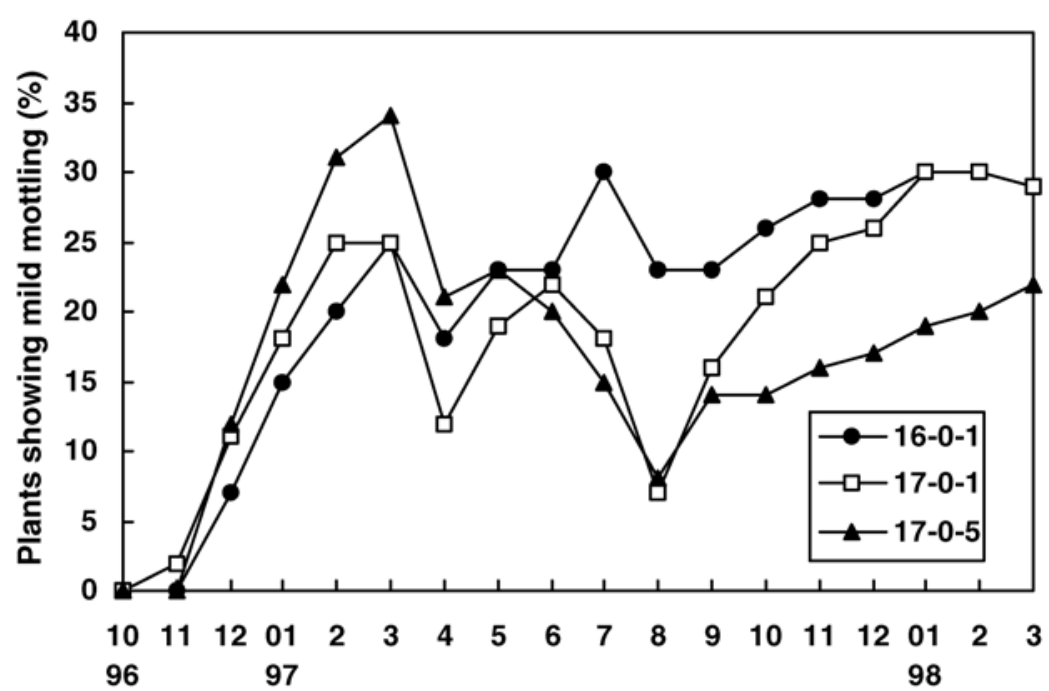

Month

B

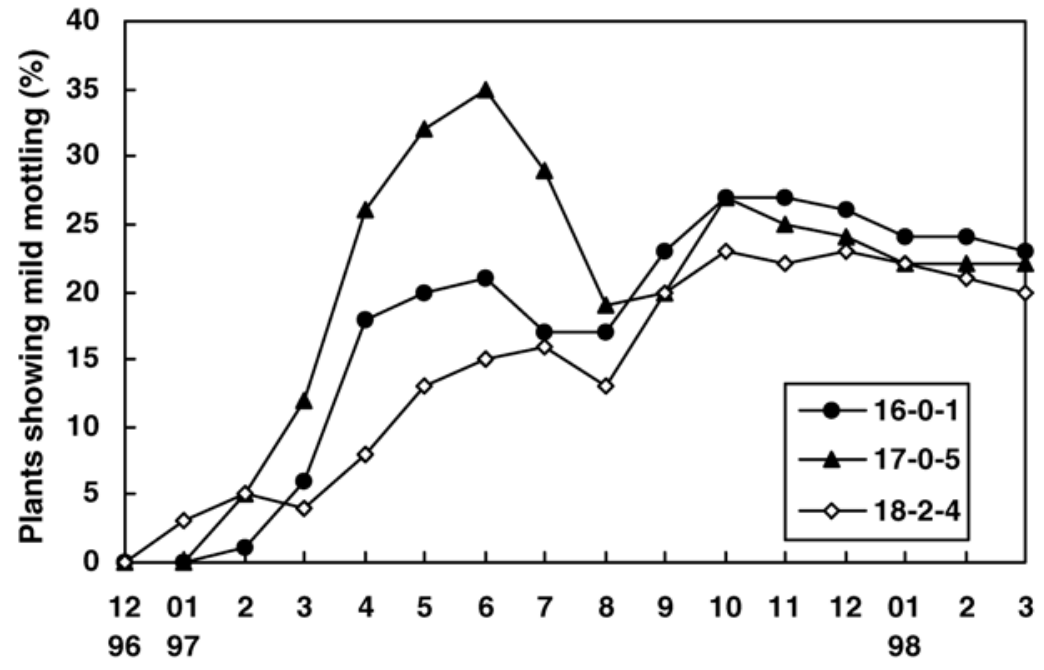

Month

Fig. 4. The fluctuation of the percentages of plants in each transgenic papaya line exhibiting mild mottling during $\mathbf{A}$, the first trial and $\mathbf{B}$, the second trial

Table 1. Variance analysis of fruit yields for transgenic papaya lines and non-transgenic control

\begin{tabular}{lcc}
\hline & \multicolumn{2}{c}{ Yield $(\mathbf{k g} / \mathbf{p l o t}) \pm \mathbf{S E}^{\mathbf{x}}$} \\
\cline { 2 - 3 } Test line & 1st trialy $^{\mathbf{y}}$ & 2nd trial \\
\hline $16-0-1$ & $500.0 \pm 26.4 \mathrm{a}$ & $375.6 \pm 5.8 \mathrm{a}$ \\
$17-0-1$ & $518.4 \pm 18.1 \mathrm{a}$ & $\ldots$ \\
$17-0-5$ & $482.0 \pm 4.1 \mathrm{a}$ & $377.9 \pm 43.3 \mathrm{a}$ \\
$18-2-4$ & $\ldots$ & $362.0 \pm 95.5 \mathrm{a}$ \\
Control & $187.0 \pm 45.3 \mathrm{~b}$ & $118.0 \pm 15.0 \mathrm{~b}$ \\
\hline
\end{tabular}

${ }^{x}$ Mean \pm standard error. Means with the same letter have no difference at a $5 \%$ significant level as analyzed by using the SAS (SAS Institute, Cary, NC) program.

y Each line harvested for 9 months.

${ }^{\mathrm{z}}$ Each line harvested for 6 months. deed, PRSV strains from South America, Jamaica, Asia, and Australia readily overcome the resistance of 55-1 seedlings in greenhouse screenings. Previous work showed that our transgenic papaya lines not only have a high level of resistance to Taiwan strains of PRSV but also to strains from Hawaii, Mexico, and Thailand under greenhouse conditions (1).

\section{LITERATURE CITED}

1. Bau, H. J., Cheng, Y. H., Yu, T. A., Yang, J. S., and Yeh, S. D. 2003. Broad-spectrum resistance to different geographic strains of Papaya ringspot virus in coat protein gene transgenic papaya. Phytopathology 93:112-120.

2. Cheng, Y. H., Yang, J. S., and Yeh, S. D. 1996. Efficient transformation of papaya by coat protein gene of papaya ringspot virus mediated by Agrobacterium following liquid-phase wounding of embryogenic tissues with carborundum. Plant Cell Rep. 16:127-132.

3. Clark, M. F., and Adams, A. N. 1977. Characteristics of the microplate method of enzymelinked immunosorbent assay (ELISA) for the detection of plant viruses. J. Gen. Virol. 34:475-483.

4. Conover, R. A. 1976. A program for development of papayas tolerant to the distortion ringspot virus. Proc. Fla. State Hortic. Soc. 89:229-231

5. Conover, R. A., and Litz, R. E. 1978. Progress in breeding papayas with tolerance to papaya ringspot virus. Proc. Fla. State Hortic. Soc. 91:182-184

6. Ferreira, S. A., Pitz, K. Y., Manshardt, R., Zee, F., Fitch, M., and Gonsalves, D. 2002. Virus coat protein transgenic papaya provides practical control of Papaya ringspot virus in Hawaii. Plant Dis. 86:101-105.

7. Fitch, M. M. M., and Manshardt, R. M. 1990. Somatic embryogenesis and plant regeneration from immature zygotic embryos of papaya (Carica papaya L.). Plant Cell Rep. 9:320324.

8. Fitch, M. M. M., Manshardt, R. M., Gonsalves, D., Slightom, J. L., and Sanford, J. C. 1992. Virus resistant papaya derived from tissues bombarded with the coat protein gene of papaya ringspot virus. Bio/Technology 10:1466-1472.

9. Gonsalves, D. 1998. Control of papaya ringspot virus in papaya: a case study. Annu. Rev. Phytopathol. 36:415-437.

10. Lius, S., Manshardt, R. M., Fitch, M. M. M., Slightom, J. L., Sanford, J. C., and Gonsalves, D. 1997. Pathogen-derived resistance provides papaya with effective protection against papaya ringspot virus. Mol. Breed. 3:161-168.

11. Manshardt, R. M. 1992. Papaya. Pages 489 511 in: Biotechnology of Perennial Fruit Crops. F. A. Hammerschlag and R. E. Litz, eds. CAB International, Wallingford, UK.

12. Murphy, F. A., Fauquet, C. M., Bishop, D. H. L., Ghabrial, S. A., Jarvis, A. W., Martelli, G. P., Mayo, M. A., and Summer, M. D. 1995. Pages 350-354 in: Virus Taxonomy. SpringerVerlag, Vienna.

13. Purcifull, D., Edwardson, J., Hiebert, E., and Gonsalves, D.1984. Papaya ringspot virus. CMI/AAB Descr. Plant Viruses. No. 292.

14. Sanford, J. C., and Johnston, S. A. 1985. The concept of parasite-derived resistance. Deriving resistance gene from the parasite's own genome. J. Theor. Biol. 113:395-405.

15. Tennant, P., Fermin, G., Fitch, M. M., Manshardt, R. M., Slightom, J. L., and Gonsalves, D. 2001. Papaya ringspot virus resistance of transgenic Rainbow and Sunup is affected by gene dosage, plant development, and coat protein homology. Eur. J. Plant Pathol. 
107:645-653.

16. Tennant, P., Gonsalves, C., Ling, K., Fitch, M. M. M., Manshardt, R. M., Slightom, J. L., and Gonsalves, D. 1994. Transgenic papaya expressing coat protein gene of a Hawaiian isolate of papaya ringspot virus and a classically cross-protected papaya show limited protection against isolates from different geographical regions. Phytopathology 84:1359-1366.

17. Wang, H. L., Yeh, S. D., Chiu, R. J., and Gonsalves, D. 1987. Effectiveness of cross protection by mild mutants of papaya ringspot virus for control of ringspot disease of papaya in Taiwan. Plant Dis. 71:491-497.

18. Yeh, S. D., and Gonsalves, D. 1984. Evaluation of induced mutants of papaya ringspot virus for control by cross protection. Phytopathology 74:1086-1091.

19. Yeh, S. D., and Gonsalves, D. 1985. Translation of papaya ringspot virus RNA in vitro: detection of a possible polyprotein that is processed for capsid protein, cylindrical-inclusion protein, and amorphous-inclusion protein. Virology 143:260-271.
20. Yeh, S. D., and Gonsalves, D. 1994. Practices and perspectives of control of papaya ringspot virus by cross protection. Adv. Dis. Vector Res. 10:237-257.

21. Yeh, S. D., Gonsalves, D., Wang, H. L., Namba, R., and Chiu, R. J. 1998. Control of papaya ringspot virus by cross protection. Plant Dis. 72:375-380.

22. Zee, F. T. P. 1985. Breeding for papaya ringspot virus tolerance in solo papaya. Carica papaya L. Doctoral dissertation, University of Hawaii, Honolulu. 